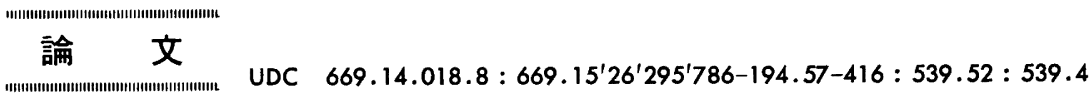

\title{
$\mathrm{Ti}$ 添加低 C, $\mathrm{N}-17 \% \mathrm{Cr}$ ステンレス鋼薄板の 加工性*
}

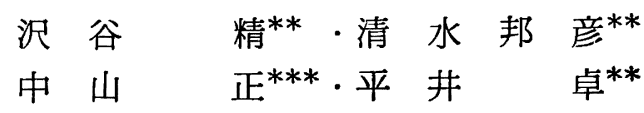

\section{The Formability of $\mathrm{Ti}$ Stabilized Low C, N-17\% Cr \\ Stainless Steel Sheets \\ Tadashi Sawatani, Kunihiko ShImizu, \\ Tadashi NAKayama, and Takashi HiRAI}

Synopsis:

Press formability of $\mathrm{T}$ i-stabilized low $\mathrm{C}, \mathrm{N}-17 \% \mathrm{Gr}$ stainless steel is evaluated by various model forming experiments in comparison with SUS430 and SUS304.

Ti-stabilized steel is superior to SUS430 but inferior to SUS304 in ductility, deep drawability, and secondary formability. Ti-stabilized steel achieves deep drawability almost equal to that of SUS304 when a new ester type synthetic lubricant is applied.

Ti-stabilized steel is very supeior to SUS430 in ridging but this steel is not immune from surface wrinkle after pressing because there is a tendency of easy grain coarsning. The surface wrinkle appears as a result of simultaneous occurrence of ridging and orange peal and increases linearlly as the equivalent strain of the deformed part increases. The tendency is improved by a single cold rolling process with high cold reduction.

\section{1. 緒言}

フェライト采ステンレス鋼板の加工性は打もに $r$ 值に よつて支配されることはよく知られている1)，前報2に おいて，低 $\mathrm{C}, \mathrm{N}-17 \% \mathrm{Cr}$ ステンレス鋼に $\mathrm{Ti}$ 添加する ことにより $r$ 值が著しく改善され， $r$ 值改善関する製 造条件の影響および集合組織的検討結果について報告し た. 本報で， $\mathrm{Ti}$ 添加低 $\mathrm{C}, \mathrm{N}-17 \% \mathrm{Cr}$ ステンレス鋼の 加工性について SUS 430 およびSUS 304 と比較しなが ら検討した結果について報告する.

\section{2. 実}

験

\section{1 実験試料}

(1) 化学成分

$\mathrm{Ti}$ 添加量を変えた 実験室真空溶解材の化学成分を, Table 1 に示す. Ti 添加材を含めて現場製造材の化学 成分を Table 2 に示す.

(2) 熱延板製造条件

真空溶解材は高周波炬にて $45 \mathrm{~kg}$ の鋼塊を溶製し， $1100^{\circ} \mathrm{C} て ゙ 1 \mathrm{~h}$ 均熱後 $110 \mathrm{~mm}$ 角の鋼塊からくり返し 2 回の熱延で $3.8 \mathrm{~mm}$ の板厚の熱延板とした. 現場製造材
Table 1. Chemical analyses of vacuum melted stainless steel sheets $(\mathrm{wt} \%)$.

\begin{tabular}{|c|c|c|c|c|c|c|c|c|}
\hline Samples & $C$ & $S i$ & $M n$ & $P$ & $S$ & $C_{r}$ & $T_{i}$ & $N$ \\
\hline$V F-0 \% \mathrm{Ti}$ & 0.004 & 0.03 & 0.05 & 0.013 & 0.002 & 16.4 & $\mathrm{Tr}$ & 0.0058 \\
\hline $\mathrm{VF}-0.2 \% \mathrm{Ti}$ & 0.006 & 0.4 & 0.41 & 0.019 & 0.007 & 16.5 & 0.17 & 0.0037 \\
\hline $\mathrm{VF}-0.4 \% \mathrm{Ti}$ & 0.006 & 0.4 & 0.41 & 0.019 & 0.007 & 16.5 & 0.40 & 0.0038 \\
\hline $\mathrm{VF}-0.6 \% \mathrm{Ti}$ & 0.006 & 0.4 & 0.41 & 0.019 & 0.007 & 16.5 & 0.64 & 0.0040 \\
\hline
\end{tabular}

Table 2. Chemical analyses of commercial stainless steel sheets $(\mathrm{wt} \%)$.

\begin{tabular}{|c|c|c|c|c|c|c|c|c|c|c|}
\hline Materials & $\mathrm{C}$ & $\mathrm{Si}$ & $\mathrm{Mn}$ & $\mathrm{P}$ & $\mathrm{S}$ & $\mathrm{Ni}$ & $\mathrm{Cr}$ & $\mathrm{Ti}$ & $\mathrm{Al}$ & $\mathrm{N}$ \\
\hline Ti-LC, N-17\%Cr & 0.006 & 0.21 & 1.39 & 0.027 & 0.008 & 0.10 & 16.66 & 0.26 & 0.049 & 0.0075 \\
\hline SU S 304 & 0.070 & 0.66 & 0.99 & 0.029 & 0.011 & 8.75 & 18.51 & - & - & 0.0173 \\
\hline SU S 430 & 0.051 & 0.59 & 0.49 & 0.027 & 0.005 & 0.14 & 16.76 & - & 0.061 & 0.0250 \\
\hline
\end{tabular}

もおもに $3.8 \mathrm{~mm}$ の板厚の熱延板を使用したが，肌荒れ 性改善を目的とした実験の場合一部 $5.5 \mathrm{~mm}$ の板厚の熱 延板を用いた。

（3）冷延板筡造条件

* 昭和 51 年 9 月 8 日受付 (Received Sep. 8, 1976)

** 新日本製鉄 (株) 光製鉄所 (Hikari Works, Nippon Steel Corp., 3434 Shimada Hikari 743)

*** 新日本製鉄(株)生産技術研究所 (Process Technology R \& D Laboratories, Nippon Steel Corp., Kitakyushu 805) 


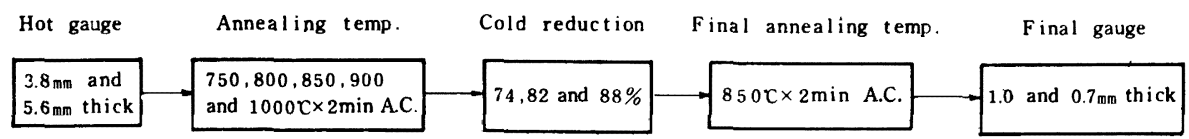

Fig. 1. Single cold rolling processing.
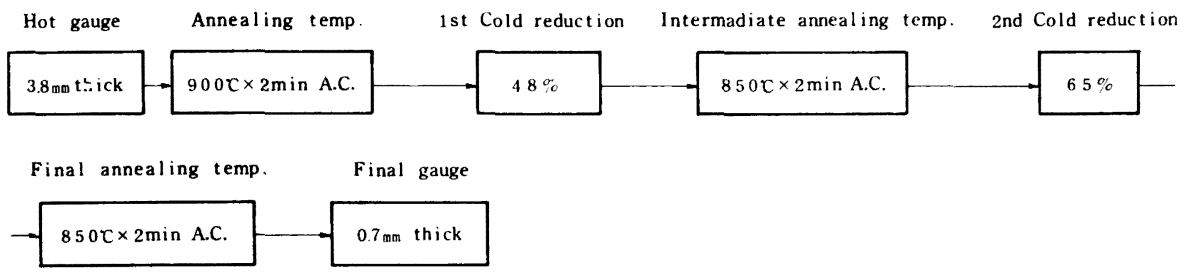

Fig. 2. Double cold rolling processing.

1段冷延条件を Fig. 1 に示す. 板厚は $0.7 \mathrm{~mm}$ およ び $1.0 \mathrm{~mm}$ を用いた。

2 段冷延条件を Fig. 2 に示す. 板厚は $0.7 \mathrm{~mm}$ を用 いた．本実験で用いた SUS 430 はすべて Fig. 2 に示す 条件で 2 段冷延された現場製造枋である.

肌あれの改善を目的とした実験においては 1 段冷延条

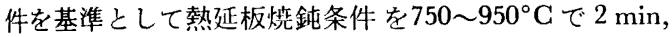
および冷延率を $87 \%$ まで変えて検討した。

\section{2 実験方法}

(1) 引張試験

インストロン型 $10 \mathrm{t}$ 万能引張試験機を用い, JIS I3号 B 型試験片を用いた.

r值は $15 \%$ 引張後, およびリジングは $20 \%$ 引張後 測定した.リシングは，小坂式触針粗度計（触針先端半 径 $5 \mu$ )を用いた。

（2）模型成形性試験

自動型万能深絞り試験機（東京試験機製作所製）を用 いエリクセン試験は JISZ 2247 により 1 号試験片,

A法で，潤滑刜はグラフォイトグリースを使用した。コ ニカルカップ試験は JISZ 2249 により打扳き円板試験 片, 工具 17 型で潤滑郕はマシン油 1 号（JISK2214）を 試験片両面に塗布して行つた。

(3) 成形限界曲線の測定法

菊間らの方法3) に従つて, Fig. 3 に示すブランク幅の ことなる短册形試験片を用い潤滑剂を変えてそれぞれの 変形径路の最大伸び $\left(e_{x}\right)$ およびそれに直角方向の伸び $\left(e_{y}\right)$ を $1 / 4^{\prime \prime}$ 径のスクライブドサークルを用いて測定し 成形限界曲線を求めた。

(4) 絞り性試験

Table 3 に示す試験条件によつて, 角筒絞り, 円筒絞 りおよび 2 次成形性試験を行つた。
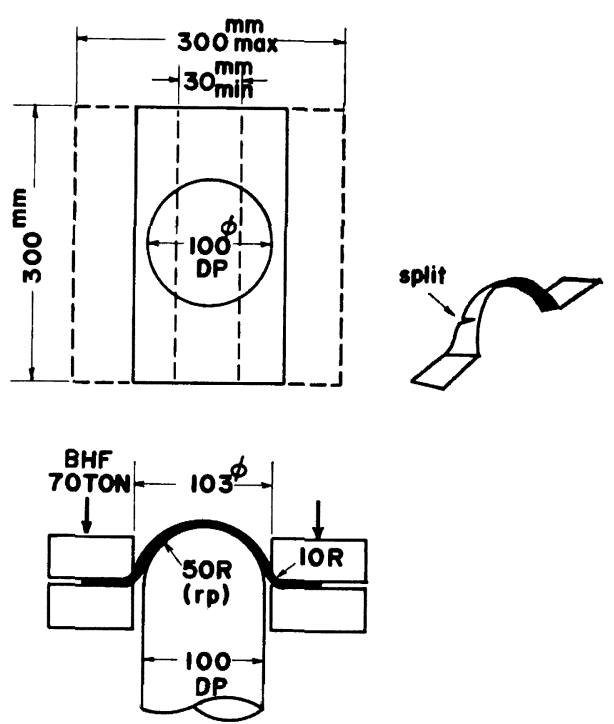

Fig. 3. Experimental method for forming limit diagrams.

\section{3. 実験結果および考察}

\section{1 引張特性および模型成形性}

3・1.1 引張特性におよぼす $\mathrm{Ti}$ 添加の影響

引張特性におよぼす Ti 添加の影響を Fig. 4 に示す. $\mathrm{Ti}$ 添加量の増大に伴い引張強さは上昇する。降伏点は $\mathrm{Ti}$ 無添加材に比べて $0.2 \% \mathrm{Ti}$ 添加材で一たん低下し, それ以上の $\mathrm{Ti}$ 添加で再び上昇与る. 伸びは Ti 無添加 材よりも $0.2 \% \mathrm{Ti}$ でやや改善されるが，それ以上の $\mathrm{Ti}$ 添加で劣化する.

Fig. 4 に結晶粒度もあわせて示すように， Ti 無添加 材の強度が低く伸びが高いのは結晶粒度が大きいことも 影響していることがわかる. 再結晶率と硬度の温度によ る変化におよぼす Ti 添加の影響を Fig. 5 に示す. 熱処 
Table 3. Testing condition for various formabilities.

\begin{tabular}{|c|c|c|c|c|c|c|c|c|}
\hline \multirow{2}{*}{ Formability test } & \multicolumn{3}{|c|}{ Punch dimension } & \multicolumn{2}{|c|}{ Die dimension } & \multirow{2}{*}{$\begin{array}{c}\text { Blank size } \\
(m \infty)\end{array}$} & \multirow{2}{*}{$\begin{array}{l}\text { B lank } \\
\text { holder force } \\
\quad \text { (TON) }\end{array}$} & \multirow{2}{*}{ Lubricant } \\
\hline & $\begin{array}{c}\text { punch dia. } \\
(\mathbf{m})\end{array}$ & $\begin{array}{c}\text { shoulder rad. } \\
(\mathbf{m})\end{array}$ & $\begin{array}{l}\text { bot tom } \\
\text { shape }\end{array}$ & $\begin{array}{c}\text { die dia. } \\
(\mathbf{m})\end{array}$ & $\begin{array}{l}\text { shoulder rad. } \\
(m a)\end{array}$ & & & \\
\hline $\begin{array}{l}\text { Rectangular cylinder } \\
\text { drawing }\end{array}$ & $100 \phi$ & $10 \mathrm{r}$ & flat & 103ф & $5 \mathrm{r}$ & $210 \times 210$ & $7 \sim 60$ & $\begin{array}{l}\text { Johnson wax } 122 \$ \text { : machine oil } 1 \\
\quad=1: 1\end{array}$ \\
\hline \multirow{3}{*}{$\begin{array}{l}\text { Circular cylinder } \\
\text { drawing }\end{array}$} & $100 \phi$ & $10 \mathrm{r}$ & round & $103 \phi$ & $10 \mathrm{r}$ & $190 \sim 230 \phi$ & 20 & \multirow{3}{*}{$\begin{array}{l}\text { J.W. 122\#: machine oil } 1 \#=1: 1 \\
\text { J.W. 122\# } \\
\text { J.W. 700\# } \\
\text { Ester type synthetic lubricant }\end{array}$} \\
\hline & $100 \phi$ & $5 r$ & round & $103 \phi$ & $10 \mathrm{r}$ & $190 \sim 230 \phi$ & 5 & \\
\hline & $100 \phi$ & $5 r$ & flat & $103 \phi$ & $10 \mathrm{r}$ & $190 \sim 230 \phi$ & 5 & \\
\hline \multirow[t]{2}{*}{ Double stage forming } & 1 st. $>50 \phi$ & $5 r$ & plat & $53 \phi$ & $3 \mathrm{r}$ & $120 \phi$ & 1 & Ester type synthetic lubricant \\
\hline & $\langle 2$ nd. $\rangle 68 \phi$ & $10 \mathrm{r}$ & flat & $71 \phi$ & $5 \mathrm{r}$ & $120 \phi$ & 20 & No lubricant \\
\hline
\end{tabular}

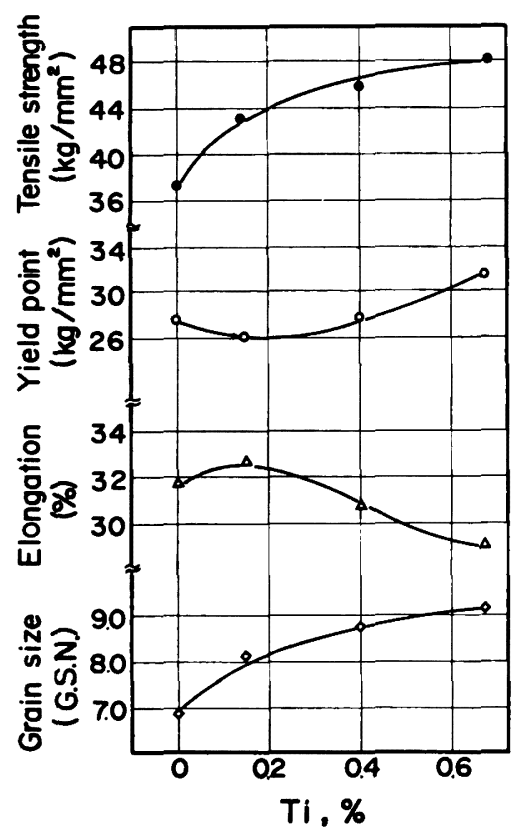

Fig. 4. Effect of Ti addition on tensile properties and grain size of low $\mathrm{C}, \mathrm{N}-17 \% \mathrm{Cr}$ stainless steels. (Single cold rolling)

理条件としては各温度での $2 \min$ 保定を用いだ．この結 果から，本実験で使用した $850^{\circ} \mathrm{C}$ の最終焼鈍温度では $0.4 \%$ 以上の $\mathrm{Ti}$ 添加材は完全に再結晶を終了していな いことがわかる. 再結晶がいずれの $\mathrm{Ti}$ 量でも完了する $900^{\circ} \mathrm{C}$ での硬度を $[\mathrm{Ti}]_{\text {free }}=(\% \mathrm{Ti})-4 \times(\% \mathrm{C})-3.86$ $\times(\% \mathrm{~N})-1.5 \times(\% 0+\% \mathrm{~S})$ で整理すると Fig. 6 のよう になり,引張強さに換算して約 $10 \mathrm{~kg} / \mathrm{mm}^{2} /(\% \mathrm{Ti})$ の 固溶体硬化が認められる.

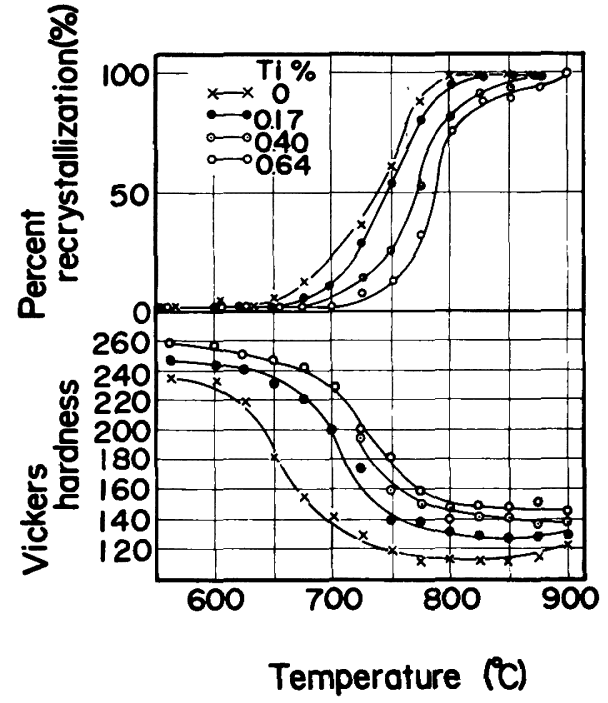

Fig. 5. Effect of $\mathrm{Ti}$ addition on hardness and recrystallization temperature of low $\mathrm{C}$, $\mathrm{N}-17 \% \mathrm{Cr}$ stainless steels. (Other variables based on the single cold rolling of Fig. 1)

\section{$3 \cdot 1 \cdot 2$ 降伏点におよぼす $\mathrm{Ti}$ 添加の影響}

種々の製造条件を用いて結晶粒度を变化させた材料に ついて, 結晶粒径と下降伏点の関係を Fig. 7 に示す. 多結晶鉄の結晶粒径と下降伏点 $\left(\sigma_{y}\right)$ との関係は Petch の関係)としてよく知られている

$$
\sigma_{y}=\sigma_{0}+k_{y} d^{-1 / 2}
$$

なる式でよく整理される，ここで， $\sigma_{0}$ は転位の運動に 対する摩擦力, $k_{y}$ は定数, $d$ は平均結晶粒径である.

Fig. 7 より, Ti 添加材は無添加材に比べて $k_{y}$ の值が小 


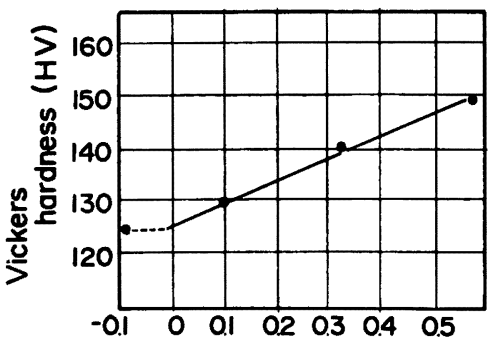

(Ti) free $=(\% \mathrm{Ti})-4 \times(\% \mathrm{C})-3.86 \times(\% \mathrm{~N})$ $-1.5 \times(\% 0+\% S)$

Fig. 6. Effect of $[\mathrm{Ti}]_{\mathrm{free}}$ on Vickers hardness of low $\mathrm{C}, \mathrm{N}-17 \% \mathrm{Cr}$ stainless steel with $\mathrm{Ti}$. (Recrystallization temperature : $900^{\circ} \mathrm{C}$ )

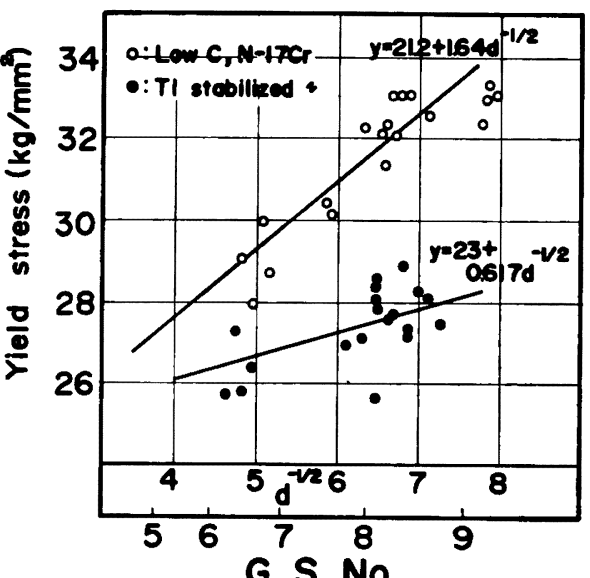

Fig. 7. Relation between grain size and yield stress of $\mathrm{Ti}$ stabilized low $\mathrm{C}, \mathrm{N}-17 \% \mathrm{Cr}$ stainless steel compared with low $\mathrm{C}, \mathrm{N}$ $17 \% \mathrm{Cr}$ stainless steel. ( $d$ : grain size diameter)

さく下降伏点の結晶粒度依存性が小さいことがわかる. この特徴は Ti 添加した炭素鋼においても認められてい る5). 定数 $k_{y}$ は, 粒界近傍に新しく転位を発生させるに 要する力が大きいほど大きくなることが知られており, $\mathrm{Ti}$ 添加により鋼中の $\mathrm{C}, \mathrm{N}$ が $\mathrm{Ti}$ で強く固定されマト リックスが純化されるため， $k_{y}$ が小さくなると考えら れる.

一般に，薄鋼板をプレス成形する際加工破断とは別に 問題となるべコ，しわ，スプリングバックなどの形状欠 陷を防止するためには, 降伏点を低くすることが望まし いことが知られている6). Ti 添加低 C, N-17\%Crステン レス鋼は Fig. 7 から明らかなように SUS 430 に比べて 降伏点が低く, かつ結晶粒が小さくなるほどその傾向が 著しくなることは，この点において望ましいことがわか

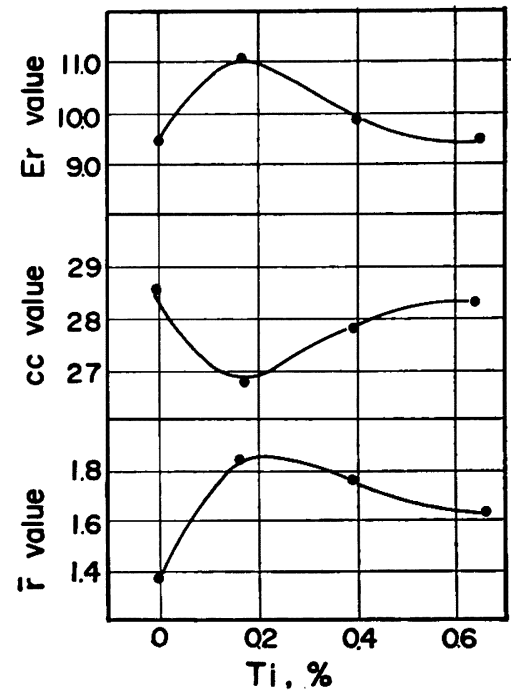

Fig. 8. Effect of $\mathrm{Ti}$ addition on Ericksen, conical cup, and $\bar{r}$ value of low $\mathrm{C}, \mathrm{N}-17 \%$ $\mathrm{Cr}$ stainless steel. (Single cold rolling)

る.

\section{$3 \cdot 1 \cdot 3$ 模型成形性におよほす $\mathrm{Ti}$ 添加の影響}

エリクセン值拉よびコニカルカップ值におよぼす $\mathrm{Ti}$ 添加の影響を Fig. 8 に示す. 図中に $\bar{r}$ 值の変化もあわ せて示してあるが，Ti 添加材の模型成形性の向上は $\vec{r}$ 值の向上とよく対応していることがわかる.

\subsubsection{Ti 添加量と材質}

引張特性, エリクセン值, コニカルカップ值および $r$ 值におよぼす Ti 添加量の影猳を検討した結果，また前 報で報告した 影響を総合的に考察すると，本報で用いた製造条件では Ti 添加量は $0.2 \sim 0.3 \%$ 程度が材質上最も望ましいこと がわかる. 以下， $\mathrm{Ti}$ 添加低 $\mathrm{C}, \mathrm{N}-17 \% \mathrm{Cr}$ ステンレス 鋼の試験出鋼を行い，現場生産設備を用いて製造した広 幅の薄鋼板について加工性を SUS 430 および SUS 304 と比較した結果について報告する.

\section{2 加工性}

\section{$3 \cdot 2 \cdot 1$ 機械的性質}

実験に用いた薄鋼板の機械的性質, $r$ 值, 模型成形性, 粒度などを Table 4 に示す. Ti 添加低 C, N-17\% Cr ステンレス鋼は，1段冷延工程でも 2 段冷延でも製造さ れた SUS 430 に比べて軟質で延性および模型成形性に 優れているが，SUS 304 に比べると延性および模型成形 性が劣ることがわかる.

\section{$3 \cdot 2 \cdot 2$ 集合組織と面内異方性}

実験に用いた薄鋼板の板面法線方向についての逆極点 
Table 4. Tensile properties, formability, and grain sizes of commercial stainless steel sheets.

\begin{tabular}{|c|c|c|c|c|c|c|c|c|c|c|c|c|c|c|c|c|c|c|c|c|}
\hline \multirow{2}{*}{ Materials } & \multicolumn{3}{|c|}{$\begin{array}{c}\text { Yield point } \\
(\mathrm{k} / \mathrm{m} / \mathrm{i})\end{array}$} & \multicolumn{3}{|c|}{$\begin{array}{c}\text { Tensile strength } \\
(\mathrm{k} q / \mathrm{m})\end{array}$} & \multicolumn{3}{|c|}{$\begin{array}{c}\text { Elongat i on } \\
(\%)\end{array}$} & \multicolumn{3}{|c|}{$\mathrm{n}$ value } & \multicolumn{4}{|c|}{ r value } & \multirow{2}{*}{ Er. } & \multirow{2}{*}{ c.c.v. } & \multirow{2}{*}{$\begin{array}{c}\text { Grain } \\
\text { size }\end{array}$} & \multirow{2}{*}{$\begin{array}{c}\text { Hardness } \\
\text { (Hv) }\end{array}$} \\
\hline & L & $45^{\circ}$ & C & L & $45^{\circ}$ & C & $\mathrm{L}$ & $45^{\circ}$ & $\mathrm{C}$ & L & $45^{\circ}$ & C & $\mathrm{L}$ & $45^{\circ}$ & $\mathrm{C}$ & $\overline{\mathbf{r}}$ & & & & \\
\hline $\mathrm{Ti}-\mathrm{LCN}-17 \% \mathrm{Cr}$ & 29.2 & 33.1 & 30.8 & 43.3 & 46.1 & 43.6 & 33.5 & 30.0 & 34.0 & 0.24 & 0.22 & 0.23 & 1.80 & 1.36 & 2.26 & 1.69 & 10.8 & 45.5 & 6.2 & 142 \\
\hline SUS 304 & 26.6 & 26.2 & 26.5 & 65.9 & 61.9 & 62.7 & 53.0 & 58.0 & 59.0 & 0.50 & 0.48 & 0.50 & 0.92 & 1.04 & 0.96 & 0.99 & 14.1 & 45.0 & 6.8 & 197 \\
\hline SUS 430 & 33.4 & 37.1 & 35.9 & 51.2 & 53.1 & 51.8 & 28.0 & 24.5 & 27.2 & 0.19 & 0.18 & 0.19 & 1.10 & 1.80 & 1.50 & 1.05 & 9.9 & 48.2 & 9.2 & 171 \\
\hline
\end{tabular}

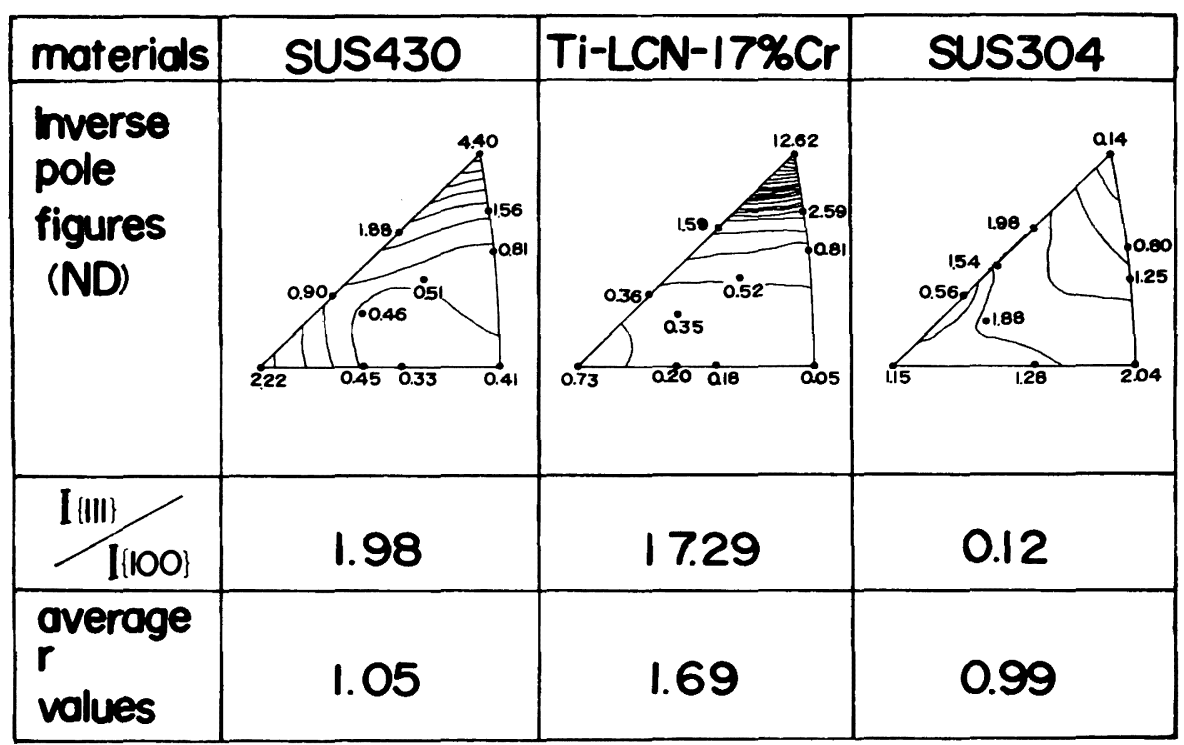

Fig. 9. Inverse pole figures of the recrystallized textures of commercial stainless steel sheets.

困をFig. 9 を示す，同じ B.C.C. 結晶構造を有する Ti 添加低C, N-17\%Cr ステンレス鋼とSUS 430 比較すると 前者は板面に平行な $\{111\}$ 面強度が強く, $\{001\} \sim\{110\}$ の間の面強度が小さく，よく知られているように I $\{111\}$ $/ \mathrm{I}\{001\}$ の強度比と $r$ 值とはよく対応している. Ti 添 加材のすぐれた 〈225〉方位集積を有する再結晶集合組織に起因する.

F.C.C.結晶構造の SUS 304 の集合組織は B.C.C.の 材料とはことなり，I I 111$\} / I\{001\}$ の強度比も $\bar{r}$ 䛧も低 いが，SUS 304の加工性がTi添加材よりもすぐれている のはテ值ではなくすぐれた延性によつて与えられる7).

実際のプレス加工に対して重要な問題は耳の発生であ

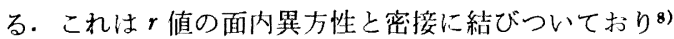
円筒絞りにおける耳発生と原板の $r$ 值面内異方性をFig. 10 に示す. $r$ 値の面内異方性は通常 $J r=\left\{r_{0} \circ-2 \times r_{45}\right.$ 。 $+r_{90} 0^{\circ} / 2$ で現わされるが, Ti 添加材は他の二者に比べ て $\Delta r$ が大きく,耳の発生状況もはげしいことがわかる. $\mathrm{Ti}$ 添加材の $\Delta r$ は，前報で示したように1段冷延の冷延

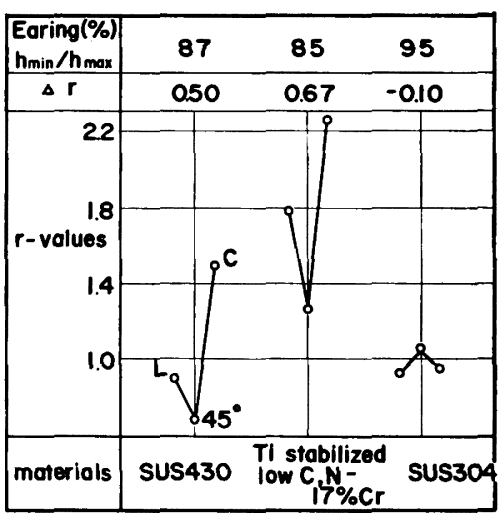

Fig. 10. Relationship between earing and planer anisotropy of $r$-values of commercial stainless steel sheets.

率を高くすることにより小さくなり，90\%以上では逆に マイナスの值となる. 本実験の試料は冷延率 74\% であ り，90\% 近くまで泠延率を高めることにより耳の発生 
は大幅に改善されよう。

\section{$3 \cdot 2 \cdot 3$ 成形限界曲線}

成形限界曲線を Fig. 11 に示すように, 1 軸一平面歪 一等 2 軸引張条件の 各領域において SUS 304 が最もす ぐれ，次いで Ti 添加材, SUS 430 が最も成形性が劣る ことがわかる. しかし, 実際のプレス品の変形径路はさ らに複雑であり, 複合された変形経路の影響を含めて実 際のプレス加工の成形限界は决定される. そこで, 以下 に述べるようなシうュレート試験を実施した。

\subsection{4 限界絞り比 (Limiting Drawing Ratio)}

深絞りタイプのシミュレート試験の一つとして, 円筒 の平頭および球頭ポンチを用いて, 限界絞り比(L.D.R.) を測定した：各材料の，L.D.R. を加工硬化指数で整理 した結果を Fig. 12 に示す.これから，L.D.R.はSUS 304 が最もすぐれ Ti 添加材, SUS 430 の順で劣化する ことがわかる. 加工条件の影響としては, 平頭より球頭, 球頭ではポンチ肩半径が大きいほど L.D.R. が改善さ れることがわかる.

山田9 は HILL の平面応力場の不安定条件式より, L. D.R.におよぼすて值およびn 值の影響を示す式として

$$
\begin{aligned}
& \text { 球頭ホンチ：L.D.R. } \propto \sqrt{1+2 r}(2 \sqrt{1+\bar{r}})^{n} \\
& \text { 平頭ボンチ : L.D.R. } \propto V(1+\bar{r}) / 2\{(1+\bar{r}) / \\
& \sqrt{1+2 \bar{r}}\}^{n} \text {. }
\end{aligned}
$$

を，球頭および平頭ポンチの場合について導いている.

Fig. 12 に示したように, $\bar{r}=1.69$ の場合 $\mathrm{Ti}$ 添加材の L.D.R.を基準として（1）および（2）式から比例的に 算出される值と比較して, Ti添加材が SUS 430 よりも著 しく優れているのはおもに $r$ 值の影響であり，また平頭 ポンチでは球頭ポンチほどn值の奇与が大きくないこと がわかる.

SUS 304 の L.D.R. は，Ti 添加材よりも良好であ るが， $r=0.99$ の場合 $\mathrm{Ti}$ 添加材を基準として（1）お よび (2) 式から同様に算出される L.D.R.は, 球䫓で 2.8 および平頭で 2.1 である.これらの值を実測值と 比較してみると平頭の場合よく一致するが，球頭の場合 予想されるほど $n$ 値の影響が認められない.

\section{$3 \cdot 2 \cdot 5$ 角筒絞り試験}

しわ押え力を変えた時の成形高さを $100 \mathrm{~mm}$ の角筒絞 りで比較した結果を Fig. 13 に示す. $60 \mathrm{~mm}$ の成形高 さは材料の絞り込みを示しており，60 $\mathrm{mm}$ 以下の成形 高さはその位置で材料が破断したことを示している．角 筒絞り性も SUS 304 が最もすぐれ Ti 添加材, SUS 430 の順に劣化する.

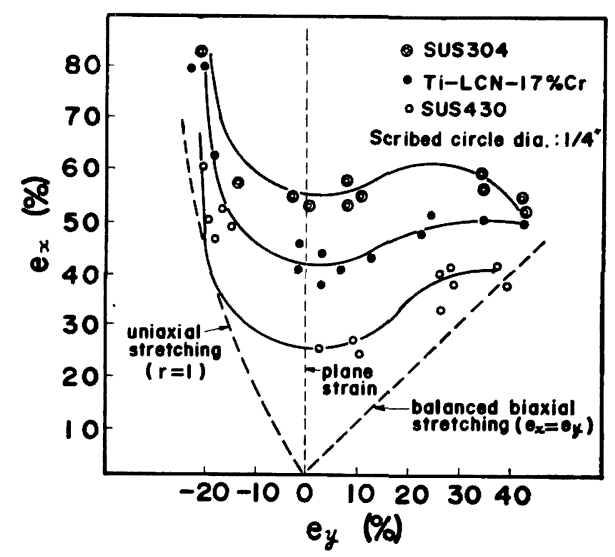

Fig. 11. Forming limit diagrams of commercial stainless steel sheets.

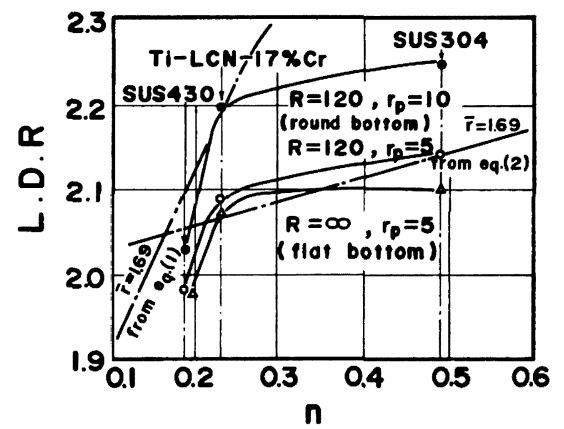

Fig. 12. Effect of work hardening indexes on limiting drawing ratios.

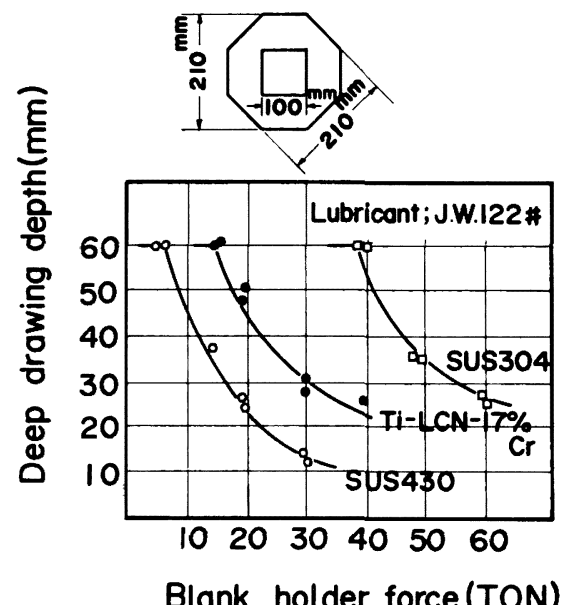

Fig. 13. Rectangular drawing test of commercial stainless steel sheets.

舟筒絞り性におよぼす潤滑の影響を検討するために， しわ押え力を $20 \mathrm{t}$ に定めて, 潤滑剂を変えて各材料の 

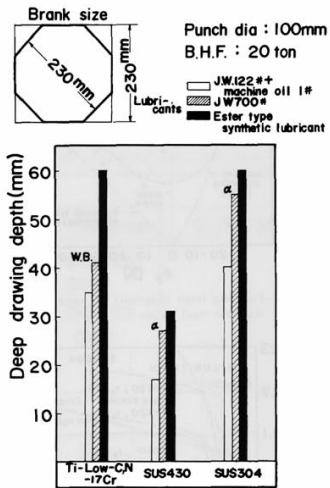

Fig. 14. Effect of lubricants on rectangular deep drawing depth of commercial stainless steel sheets. (W. B. : Wall breakage, $\alpha: \alpha$ breakage)

成形高さを比㣀した結果を Fig. 14 に示支。これから， 洞滑性能の最もすぐれたェステル系合成洞滑刘の成形高 さ改善勃果は著しく, 次いて JW 700\$, JW 122ま+マン ン油の順俋成形高さは低下するが，とくにエステル番合 成洞滑剒を使用子ることにより Ti 源加材はSUS 304 と 同程度の深絞りが可能であることか゚わかる。

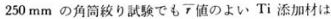
低 C, N-17\% Cr ステンレス成よりも深校り性がよい10). さらに良来 SUS 430 てはプレス不可能でSUS 304 を用 いてプレス加工されていた $550 \mathrm{~mm} \times 450 \mathrm{~mm} \times 165 \mathrm{~mm}$ 深さの一体ンンクプレスを行なつた結果, Photo. 1 に示 ナごとくプレス可能てあり，Ti 添加朴のすぐれたプレ ス加工性が确侃された。.

\section{2 .62 次成形性}

薄铜板の 2 次成形性とは，最初に市る加工を曼けた後 に引続いて别標の加工を受ける場合の加工性を指してい る.実際のプレス加工で服もよくみのられるのは深絞り加 エを受けた後リストライクで張出し加工を受ける場合な どである.このような 2 次加工の筬単なシるュレート試

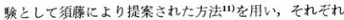

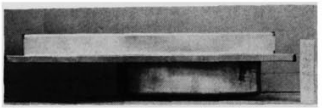

Photo. 1. Deep drawing experiment of one piece sink. (thickness : $0.7 \mathrm{~mm}$ )
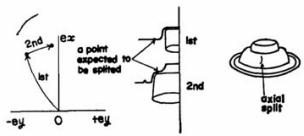

Fig. 15. The strain path of the point expected to be splited in double stage forming test. (Schematic)

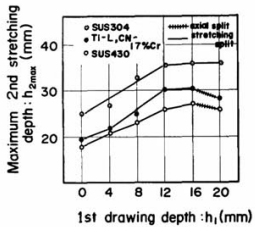

Fig. 16. Relationship between 1st drawing depth and maximum 2nd stretching depth of commercial stainless steel sheets.

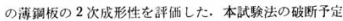
部の变形経路を摸式的に示すと Fig. 15 のようになり， ブレス加工のリストライクでの加工をシミ゙レートした ものになる. 1 段絞り高さを $h_{1}$, 材科が破断するまて の最高の 2 段粉り高さを $h_{2 \max }$. として，各材料の $h_{1}$ と h $2 \mathrm{max}$. の閦係を測定すると Fig. 16 のようになる. 2 次成形性の評面としては $h_{2 \max }$ ，の高い材祼活と2 次成 形性がすぐれていと考えられ，この結果から2次成形

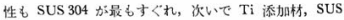
430 となるこにがかかる。興味あるのは，フェライト系 ステンレス铜は $h_{1}$ を大きくして縮みフランシ変形ひず みが增加して周方向の延性が低下してくると2段絞りて

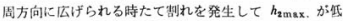
下して来るが，オーステナイト系ステンレス铜の SUS 304 ではそのようなたて割れが見られナ゙ $h_{\text {max }}$. も非常 に高いことである.この网係を变形状偡図上で表わすと 
Fig. 17 のようになる.この上うな複合された変形経路 の成形限界の検討は中島ら こで用いたような変形経路では，1段紘りが大きい汪 ど2段较りにおける成形限界は大幅に增大寸ることが 中島らにようて見出されているが，本実拨においてもこ の傾向は認められ，SUS 304 の $2 \mathbf{E}$ 絞りにおける成形限 界の增加は, Fig. 17 に示すようにフェライト系ステン レス钢と比へて著しい特徽があることがわかる。 Ti i 添 加材の 2 次成形性はSUS 430 に比べてなぐれているが, SUS 304 に比へれ估著しく劣ってょりこの点は実際の フレス加エ上注意すべき点である。なお,ここでたて梙 れと称しているの法, Photo. 2 に破面の走查型電子影微 镜の钼察結果を示すように, 一般に円筒深絞り容器など の睢壁に入る脃性的な制れではなく、それとは全く別の 延性破断である。

\section{3 .3 表面性状}

3.3.1 Ti 添加低 $\mathrm{C}, \mathrm{N}-17 \% \mathrm{Cr}$ ステンレス凩のリシ

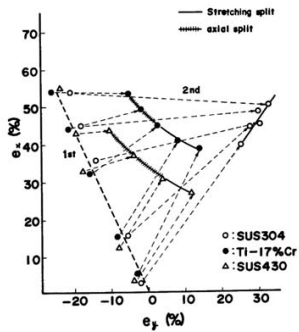

Fig. 17. $e_{x}-e_{y}$ diagrams of secondary forming test.
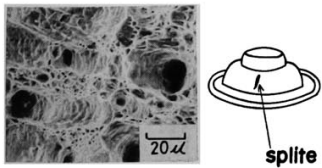

Photo. 2. Scanning microscope observation of axially splited surface in secondary forming test.
ングの特溦

一般に，フェライト采ステンレス銅薄板は冷間生延あ るいはプレス扣工などの際にリシングと呼ばれる表面欠 陷を生ずる.リジングは冷間加工を受けた際に通常压延 方向に平行に現われる板幅方向に凹凹を有兴波状の表 面父宿であり，製品衣面の外観を著しくそこなうため， 外観を重要視するステンレス铜製品の致颌的久宿となる 場合があり，赛用上大きな問題となる。

$\mathrm{Ti}$ 添加材を標海の 2 段冷延工程で製造し, 同一工程 で製造された SUS 430 のリシングと比觓するため触針 式表面组度計を用いて圧延方向に直角の表面粗度安測定 した結果を Fig. 18 に示す. Ti 添加材のリシングの特 徽は, 波状起伏が SUS 430 に比べて小さいが, 辒度咶 の先端半径の小さ店むの $(5 \mu)$ を用いると SUS 430 に 比へて凯小なふれが非常に大きいことがわかる、リシン グの形態を Photo. 3 に示子が, SUS 430 のリジングは 压延方向に長く伸びた仙凸の波状起伏が平行に亚んで、 るのに対して，Ti 源加材は短い山几が压延方向に不规 則に連らなつた形態となっている。ささらに表面龙走查型

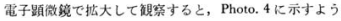

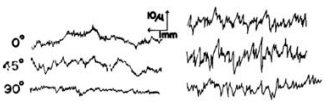

(a) SUS430

(b) Ti-LCN-17\%Cr

Fig. 18. Surface roughness profiles of $20 \%$ tensile specimens of SUS 430 and $\mathrm{Ti}$ stabilized low $\mathrm{C}, \mathrm{N}-17 \% \mathrm{Cr}$ stainless steel. (Double cold rolling)

Ti-LCN-17\%Cr

SUS 430
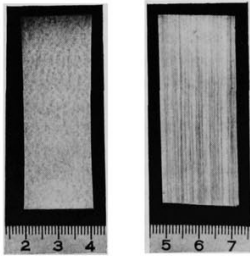

Photo. 3. Optical microscope observations of ridging of $20 \%$ tensile specimens. 


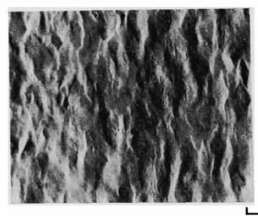

SUS 430

\section{$200 \mu$}

Photo. 4. Scanning microscope observations of surface roughness of $20 \%$ tensile specimens.

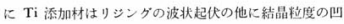
凸に起因する orange peal が大きく楒められる.この形 態上の特徽が, 粗度竍の結果に現われたものと考えられ ろ. $\mathrm{Ti}$ 添加材のリジングのもう一つの特後として, 松 村らは瓜延方向および $90^{\circ}$ 方向のリジングに比でて $45^{\circ}$ 方向のそれが大きいことを跟告している13.

リシングの発生原因は, 鋳造紐織あるいは熱延中に発

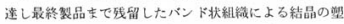
性異方性に起因することは多くの妍究者の間で一致して いる(4). Ti 添加材のリジングの形態上の特潡は, 現在

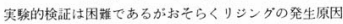
となるバンド状組较が微細化しリシングの波状起伏も微 細化されたものに，低 $\mathrm{C}, \mathrm{N}$ 化のため結晶粒が粗大化さ h, orange peal が大きくなつてりジングの被状起伏に

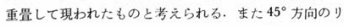
シングが特に大きくなる理由は次のように考えられる. リシングの発生機满については現在いくつかの考えがあ り，研究者間で一致を見ていない間貿であるが15，最近

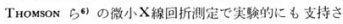

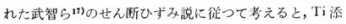
加材は強い $\{554\}\langle 225\rangle$ 方位の集乘を持つ再絬品集合粗 織を有し、この方位は, 武智らがリシング発生原因と考 えた [011] 帆縕䍃中の $\{111\}\langle 110\rangle$ 成分が压延方向加ら

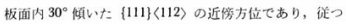
て $30^{\circ}$ に近い $45^{\circ}$ 方向厄最る大きなりシングが現われ たものと考えてよいであるう。事实松朴らは $30^{\circ}$ 方向 で最大のリシングを測定している19)。しかしながら、リ シングの原因と考えられている最終製品のパンド状組緎 に比へると通常X線で集合組絨を測定する領域は非常に 広く, 平均的な集合組織が得られるのて，同一の身合租 織が得られてもりシンの゙は全く哄つて現わ机る場合が雔 諗されており18)199，集合組織と結びつけてリシング現祭
を論ずる場合に注意すべきである。

$\mathrm{Ti}$ 添加材のリジングのこれらの特㴛は，次に述へる ブレス加工後の製品表面に現われる肌あれと関連して加 工性のすぐれた Ti 添加材では実用上重要である.

\section{3 .2 肌あれとその改善対策}

$\mathrm{Ti}$ 添加战 C, N-17\%Cr ステンレス咸は, SUS 430 に 比バると容易に粗䊉化しゃすくプレス加工なとに打いて 製品表面の肌あれが实用上問盟となる、ここで阭あれと 呼んでいるのは, Fig. 19 にSchematic に示与ようにり シンング波状起状と orange pealによる微小な凹凸の两 者の寄与を合わせた四凸を指す。

加工性のすくれた $\mathrm{Ti}$ 添加材は, 侻来 SUS 430 では 不可能であつた一体ンンクプレス加工も可能であるが, 一体シンクのコーナー部で没しい肌あれが発生し笑用上 問趋となる。この原因を $45^{\circ}$ 方向のリシング, 変形径路 および結品粒度の 3 点から検期した.プレス加工にシう ュレートし，各方向の肌あれが澌定しやすいように円筒 紋りを用い较り染さを变えてフランシ部の㞦あれを各方 向とも压延万问に直筒になるようにして測定した結果を Fig. 20 に示す. これから，45 方向の肌あれが $0^{\circ}$ と $90^{\circ}$ 方向のそれより級り深さが深くなるとやや大きくな る倾向か楒められる.

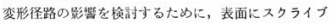
ドサータルをエっチングした铜肘を用いて，1軸引張， 円筒級りょよひ角筒級り亮行い, フランシ部の絣と横方 向のひずタを测定しこれら各点の王延方向に平行な肌 あれを相当ひずみで整理した結果を Fig. 21 に示すが， 肌あれはこれら加工方法によらず相当ひずみの增加につ れてほほ㨁線的に增大与ることがわかる。

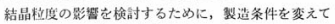

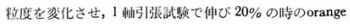
peal 在浿定した結果を Fig. 22 に示与. 


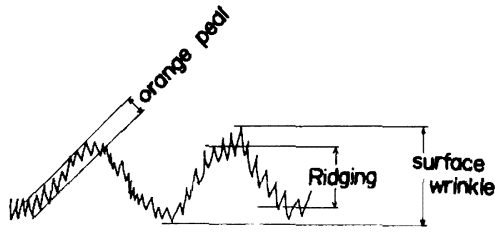

Fig. 19. Schematic view of surface wrinkle, orange peal and ridging on the surface roughness profile.

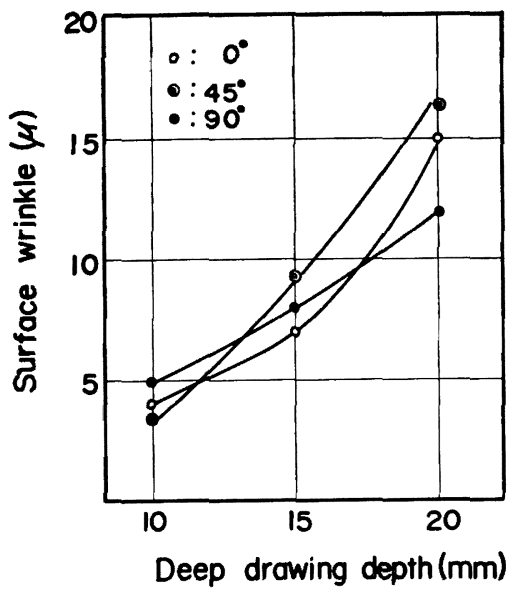

Fig. 20. Variations of surface wrinkles for specimens at $0,45,90 \mathrm{deg}$ to the rolling direction in $\mathrm{Ti}$ stabilized low $\mathrm{C}, \mathrm{N}-17$ $\%$ Cr stainless steel sheet. (Double cold rolling)

以上の検討結果から，Ti 添加材の肌あれは SUS 430 に比べて粗粒化しゃすく，加工性が侾れているため深く 絞られたこと，また角筒のコーナー部では一部では $45^{\circ}$ 方向のリシングが重畳されてより激しくなつたものと荷 えられる.これの改善刘策としては，基本的にはリシン グを改善し，細粒化してやればよいことがわかる．松村 らが指摘するように，45方向のリジングは $\{554\}\langle 225\rangle$ 再結昆粒のコロニーに起因する上寸れは， $\{554\}\langle 225\rangle$ 集 積の弱い再結晶集合組織にしてやれば，改善されるはず である・

$\mathrm{Ti}$ 添加低 C, N-17\%Cr ステンレス锎の肌あれの改善 について，大橋ら20) も検討しており，最終烍鈍温度を $850^{\circ} \mathrm{C}$ 以下として，急速加熱により細粒化するこ上によ り肌あれが改善されることを報告している. 本実䮖では 熱延板焼鈍温度の肌あれにおよぼす影響を1段冷延で検 討した. その結䌸を Fig. 23 に示すが，熱延板烍鈍温度 は $900^{\circ} \mathrm{C}$ で肌あれは極小こなることがわかる. 熱延板 焼鈍温度の上昇に伴つて冷延烍鈍板のリジングは改善さ

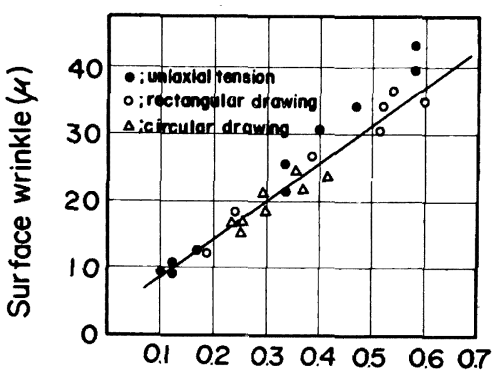

Equivalent strain

Fig. 21. Effect of equivalent strain on surface wrinkles developed by various deformation processings in $\mathrm{Ti}$ stabilized low $\mathrm{C}$, $\mathrm{N}-17 \% \mathrm{Cr}$ stainless steel sheet. (Double cold rolling)

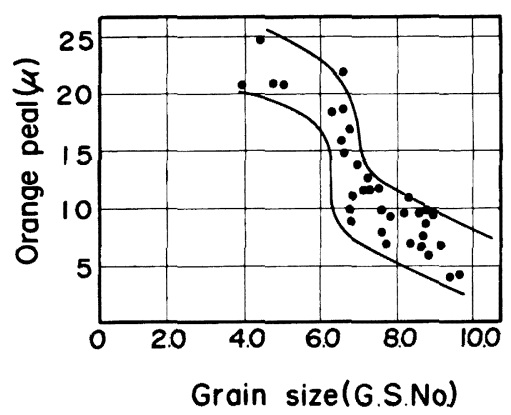

Fig. 22. Effect of grain size on the orange peal of $\mathrm{Ti}$ stabilized low $\mathrm{C}, \mathrm{N}-17 \% \mathrm{Cr}$ stainless steel sheet.

れるが，950ㄷ Cでは急激な精成長が生じそれが冷延焼鈍 板の結品粒度に影響してそれより低温で粘度番号として 9.0 以上であつた結晶䊉度が $950^{\circ} \mathrm{C}$ では 8.5 以下をで 粗粆化して orange peal 在少化するため，両者の複合で ある肌あれは $900^{\circ} \mathrm{C}$ 附近で極小になるものと考えられ る.粗粒化のたる汇は，1段冷延でその泠延率をできる だけ高くしてゃることが望安しい，熱延板燋鈍温度を $900^{\circ} \mathrm{C}$ ，冷延率を $88 \%$ ，最終焼鈍温度を $850^{\circ} \mathrm{C}$ とする ことにより 2 段冷延材より細粘化与ることができた。こ の製品の肌あれをFig. 24 に示与が，先に示した 2 段冷 延材 (Fig, 18 b) に比べて肌あれが改善されていること がわかる.

一般に，SUS 430 の材質特性は1段汾延忉に比べてす ベての点で 2 段冷延忉の方が優れているが， Ti 添加低

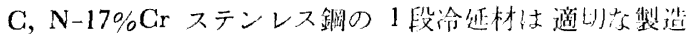
条件を朋いることにより2段们近低棌色のない性質特 性を示し2)，本鋼の材質上の弱点である肌あれについて

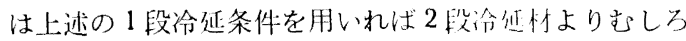




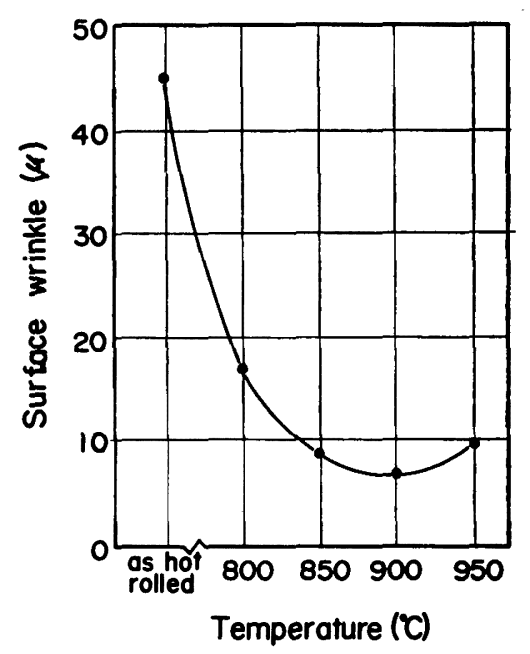

Fig. 23. Effect of annealing temperatures of hot rolled sheet on the surface wrinkle of $\mathrm{Ti}$ stabilized low $\mathrm{C}, \mathrm{N}-17 \% \mathrm{Cr}$ stainless steel sheet. (Single cold rolling, red. $=$ $82 \%$, final annealing temperature $=850^{\circ}$ C)

優れた材質を得ることができ,ここにも本鋼の特徴があ る.

\section{4. まと め}

$\mathrm{Ti}$ 添加低 $\mathrm{C}, \mathrm{N}-17 \% \mathrm{Cr}$ ステンレス鋼の加工性および 表面性状を検討した結果;

（i）加工性および表面性状の良好な薄鋼板を製造す る条件として $\mathrm{Ti}=0.2 \sim 0.3 \%$, 熱延板燒鈍温度 $900^{\circ}$ C， 1 段冷延で冷延率はできるだけ高く，最終烓鈍温 度 $850^{\circ} \mathrm{C}$ が望ましい

（ii）加工性について，成形限界曲線，角筒絞り，L. D.R. および 2 次成形性試験で検討した結果，SUS 430 よりはすぐれているが，SUS 304 にはおよばな い

（iii）しかし，潤滑性の非常にすぐれた潤滑剂を使用 するとSUS 304 と同等の深絞りが可能である

（iv） 2 次成形性はとくに SUS 304 に比べて著しく 劣つており，同じょうに深絞りできても，リストライ クなど 2 次成形性で実用上注意すべきである

（v）リジングは SUS 430 よりは優れているが，粗 粒化しゃすく，プレス加工後の肌あれが実用上問題で ある.肌あれは加工された部分の相当ひずみ量に応じ

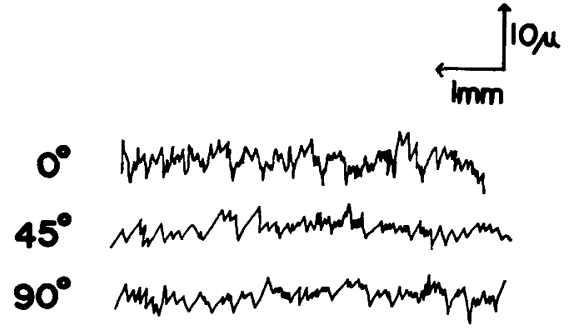

Fig. 24. Surface roughness profiles of $20 \%$ tensile specimens of $\mathrm{Ti}$ stabilized low $\mathrm{C}, \mathrm{N}-17$ $\% \mathrm{Cr}$ stainless steel sheet produced by the highly reduced single cold rolling.

てほほ直線的に大きくなり，本鋼種は加工性が優れて いるため加工後の肌あれがとくに問題となる

（vi）肌あれはりシシングと orange peal が重なつて 生じたものであり, 高圧下 1 段冷延により改善できる などが明らかになつた。

\section{交献}

1）五弓勇雄，鈴木敬治郎，猪野信吾：金属学会誌， 34 (1970), p. 516

2 ）沢谷 精，清水邦彦，中山 正，三好正則：鉄と 銅, 投稿中

3 ) $T$. Kikuma, $K$. Nakazima: Proc. ICSTIS, Suppl. ISIJ, 2 (1971), p. 827

4) 福田宣雄：「 $\mathrm{Ti}$ 添加鋼に上る超深絞り用冷延鋼板 の製造に関する研究」, (1973), p. 148

$5)$ K. Yoshida: Sci. Papers Inet. Phys. Chem. Rev. (Tokyo), 59 (1965), p. 87

7 ）五弓勇雄，鈴木敬治郎：金属学会誌，28 (1964), p. 452

8 ) J. C. Wright: Sheet Met. Ind., 42 (1965), p. 815

9 ) 山田嘉明: 機械学会誌, 67 (1964), p.524

10）清水邦彦, 山口美紀, 荒川基彦, 石崎寿夫, 沢谷 精：鉄銅協会第 89 回講演大会 (1975), p. 200

11) 須藤忠三: 住友金属, 26 (1974), p. 106

12）中島浩衛，菊間敏夫，蓮香 要：製鉄研究， 264 (1968), p. 38

13）松村 理，松尾宗次，大関芳夫，速水哲博：鉄と 鋼，投稿中

14) J. C. Wright: Sheet Met. Ind., 51 (1974), p. 263

15) H. Chao: Met. Trans., 4 (1973), p. 1183

16) $T$. $R$. Thomson and $J$. M. Baker: Proc. ICSTIS. Suppl. ISIJ, 2 (1971), p. 887

17）武智 弘, 加藤 弘, 角南達也, 中山 正: 金属 学会誌, 31 (1967), p. 717

18）沢谷 精, 荒川基彦, 清水邦彦, 大阔耕之：铁銅 協会第 88 回講演大会, (1974), p. 143

19）川原浩司：金属学会誌，38 (1974)，p. 440

20）大橋延夫他：特許公報，49-36521 